\title{
SCOUR DEVELOPMENT IN COMPLEX SEDIMENT BEDS
}

\author{
Kate Porter ${ }^{1}$, Richard Simons ${ }^{1}$, John Harris ${ }^{2}$ and Tiago Fazeres Ferradosa ${ }^{1}$
}

\begin{abstract}
Offshore windfarms are often situated in complex sediment beds made up of layers and mixtures of sands, gravels and clays. However, little is known about how these types of sediment beds actually affect the scour process. Therefore, a series of laboratory tests were conducted to test simplified cases of layered and mixed sediment beds, as a basis for improving understanding of scour in complex situations. Two sands were used in the tests; one fine and one coarse with 0.2 and $0.6 \mathrm{~mm}$ respective median grain sizes. In the layered case with fine sand as the upper layer, it was found that scour development in the underlying coarse sand was enhanced compared to scour in a uniform bed of the coarse sand. In the mixed case the shape of the scour curve was significantly altered as were the time to equilibrium and equilibrium scour depth.
\end{abstract}

Keywords: scour; clear water; current; layered sediments; mixed sediments

\section{INTRODUCTION}

Research into scour at monopile foundations has primarily focused on investigating the impact of different hydrodynamic conditions on scour in a bed of uniformly graded material. Sumer and Fredsoe (2002) and Whitehouse (1998) provide comprehensive summaries of this research. While investigation of scour in a uniform bed has enabled understanding to be gained of many of the underlying processes, often at field sites the sediment beds are much more complex, and it is little understood how complex mixtures of materials actually affect scour. Figure 1 shows a typical complex sediment bed at an offshore location. The bed consists of several layers of materials, each having different properties. Furthermore, within each layer there is a mixture of materials including differing proportions of clays, sands, and gravels.

There have been relatively few studies reported in the literature relating to scour in complex sediment beds, and most of these relate to quite specific situations. The effect of non-uniform cohesionless sediments on scour in a current under live bed conditions has been investigated by Chiew and Melville (1989) who found that equilibrium scour depth was less than or equal to scour depth in a uniform sand with the same $d_{50}$ value. Raudkivi and Ettema (1977) reported similar results under clear water conditions. The larger particles form an armour layer protecting the bed from eroding. Raudkivi and Ettema (1985) studied bed armouring by running a series of tests with a layer of coarser material overlying finer non-cohesive sediment. They found that the equilibrium scour depth reached depended on the velocity of the flow; at low velocity (low bed shear stresses), equilibrium scour depth was less in the armoured bed compared to a uniform bed of the fine sand, whereas when the bed shear stress was increased beyond a certain point scour depth became deeper in the armoured case compared to the nonarmoured bed, due to breaching of the armour layer. While these studies relate to non-cohesive sediments, the effect of cohesive material on scour development has also been investigated. Ting and Briaud (2001) found that although the equilibrium scour depth in a clay bed was comparable to scour in a sand bed, the rate of scour was much slower than in sand. Scour in more complex beds containing mixtures of cohesive and non-cohesive material has also been reported. Debnath and Chaudhuri (2010) conducted a series of laboratory tests using mixed sand clay beds under unidirectional current, and concluded that the clay content and water content influenced equilibrium scour depth. With a low water content equilibrium scour decreased as clay content increased, but for a large clay content and a larger water content, scour depth increased as clay content increased. Scour in mixed beds has been extended to different hydrodynamic conditions by Dey et al. (2011) who investigated scour in sand clay mixed beds under waves. They reported that equilibrium scour depth decreased with increasing clay content up to a certain point where the mixture then behaved as a clay bed.

These studies show that there are many key differences between scour behaviour in complex and uniform sediment beds. Furthermore, there are still significant gaps in knowledge of scour development in complex sediment beds, and many cases which have yet to be considered. This is an area where further investigation will be valuable, as improving our understanding of scour development in complex

\footnotetext{
${ }^{1}$ Department of Civil, Environmental and Geomatic Engineering, University College London,Chadwick Building, Gower Street, London, WC1E 6BT, UK

${ }^{2}$ HR Wallingford, Howbery Park, Wallingford, Oxfordshire,OX10 8BA, UK
} 
sediment beds should enable scour in more realistic field conditions to be predicted to a greater degree of accuracy, and ultimately result in more cost effective foundation design and scour protection works.

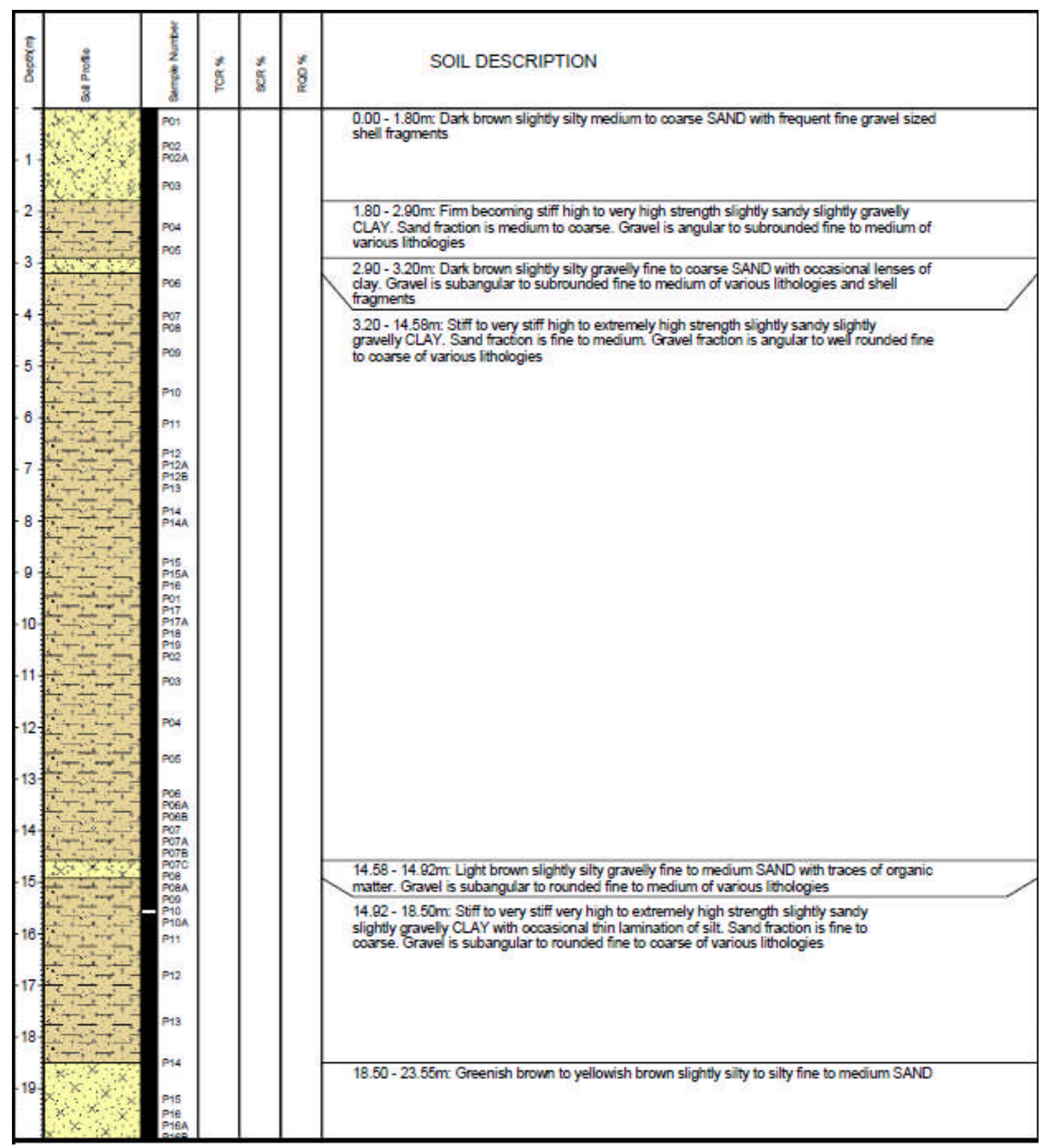

Figure 1. Typical section through a sediment bed

\section{METHODOLOGY}

In order to begin to investigate the impact of complex sediment beds on scour, a series of laboratory tests were conducted in the reversing current flume at UCL. It was decided to conduct the investigation experimentally so as to allow the unknown processes to be observed, without making any assumptions about the behavior of the materials in these complex beds, as would be necessary for a numerical study.

The tests were designed to be primarily qualitative in nature to provide initial insight into the processes occurring, and enabling important features to be determined for further fully quantitative testing.

With this in mind, a small scale facility was chosen for the tests to enable them to be carried out more practically. Tests identified for further analysis would then be run at a larger scale to quantify and help validate the results. 
All tests were run under unidirectional current in the clear water regime for scour, so as to start with a simple hydrodynamic regime for the tests. This also enabled the formation of ripples upstream of the pile to be avoided, and meant that no general lowering of the bed would occur, which would make the scour depth difficult to determine.

The time development of scour as well as the equilibrium scour depth were observed so that a fuller understanding of the scour process could be gained. The scour depth development through time during each test was monitored using a $5 \mathrm{~mm}$ scale marked onto the side of the pile. An echosounder was used to measure the spatial variation in scour depth and to obtain profiles of the scour hole slopes upstream and downstream of the pile. This allows for a more comprehensive analysis of the development of the scour hole to be undertaken. The flow velocity was measured using LDV, at the location of the pile over a flat sand bed, prior to the scour tests being conducted.

The initial test cases were designed to be markedly simplified compared to a typical bed found in the field, so that a better understanding of the underlying processes could be gained before more complex cases are tested. Although it is common in the field for the sediment beds to have clay or silt fractions, for these initial tests it was decided to use only non-cohesive material so that the influence of cohesion on scour was not a factor. While field sites often contain cohesive materials, there are also many instances where non-cohesive layers and mixtures occur naturally, as reported by Whitehouse et al. (2010). Therefore, investigation into complex non-cohesive beds is useful in its own right as well as providing a basis from which to investigate more complex sediment beds containing fractions of cohesive material.

\section{EXPERIMENTAL SET-UP}

Two simplified cases were identified for initial testing, one a layered bed, the other a mixed bed. Both consisted of just two sizes of uniformly graded sand, a fine sand with $\mathrm{d}_{50}=0.2 \mathrm{~mm}$, and a coarse sand with $\mathrm{d}_{50}=0.6 \mathrm{~mm}$. The sand sizes were selected to be of different yet comparable sizes so that scour would occur in both sands under the same velocity, without reaching live bed conditions for either of the sands. In the layered case these were arranged one overlying the other (figure $2 \mathrm{a}$ and figure 3 ). The mixed bed (figure $2 b$ ) was made up of equal proportions of fine to coarse sand in the mixture.

In order to compare these tests with the well researched case of scour in a uniform sand bed, the fine and coarse sands were each tested on their own. Comparison between these uniform cases and the complex cases will enable the differences in scour behaviour to be clearly identified.

a)

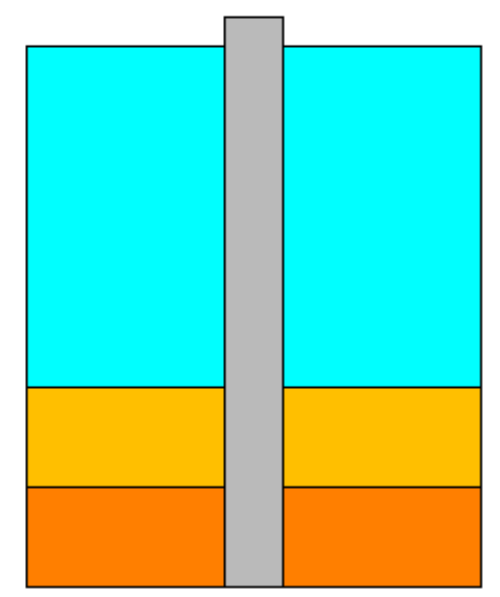

b)

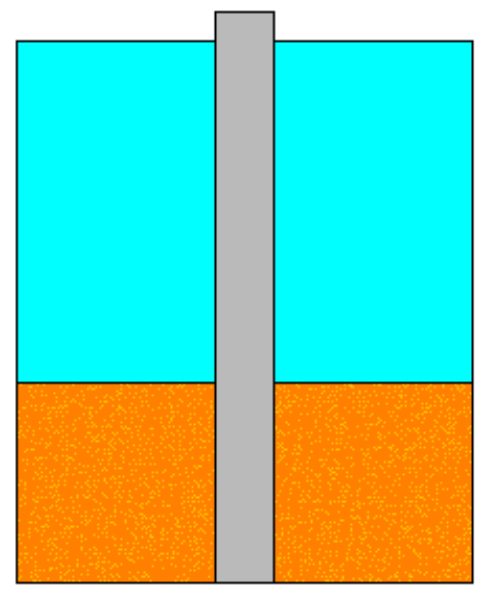

Figure 2. a) layered bed configuration b) mixed bed configuration 


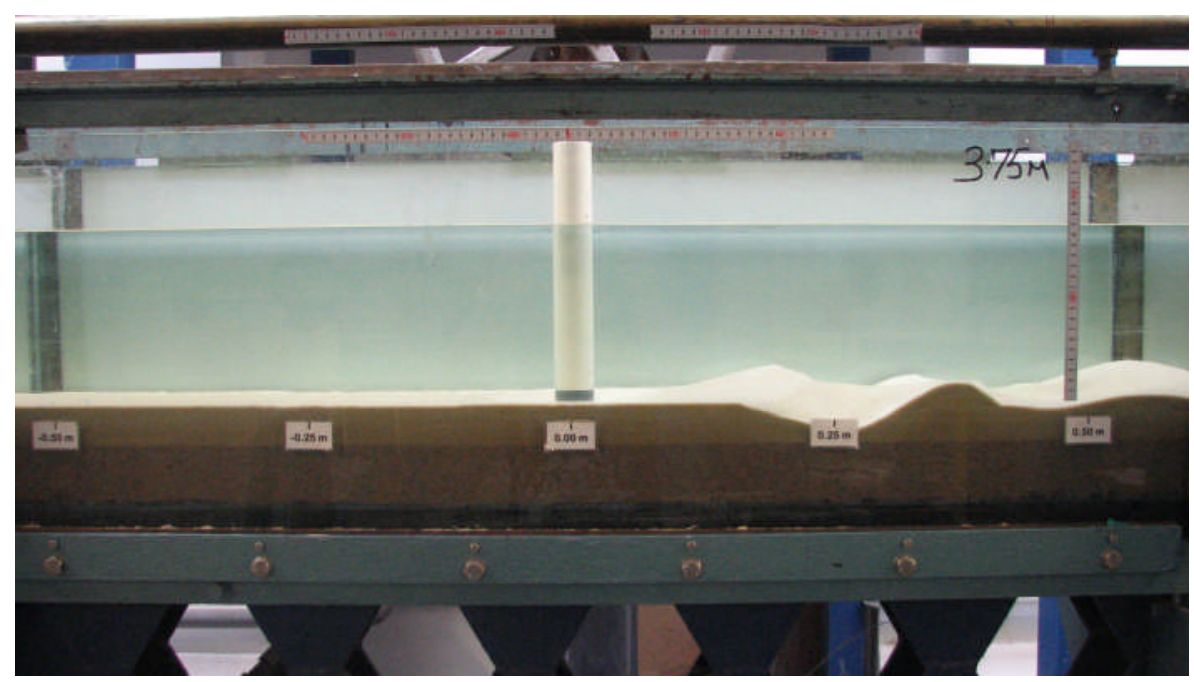

Figure 3. Layered bed test set-up

Figure 4 shows the test set-up in the flume. A false bed lies $10 \mathrm{~cm}$ above the base of the flume along its length, either side of a sand bed section $2 \mathrm{~m}$ long. A smooth transition between the false bed and sand bed was achieved through curved end sections to the false bed. The $10 \mathrm{~cm}$ bed depth was designed to allow at least 2D scour depth, which is greater than the maximum scour depth anticipated during the tests under the chosen velocity. The water depth was set at $17 \mathrm{~cm}$ so that this parameter would not strongly influence the scour process (Whitehouse, 1998).

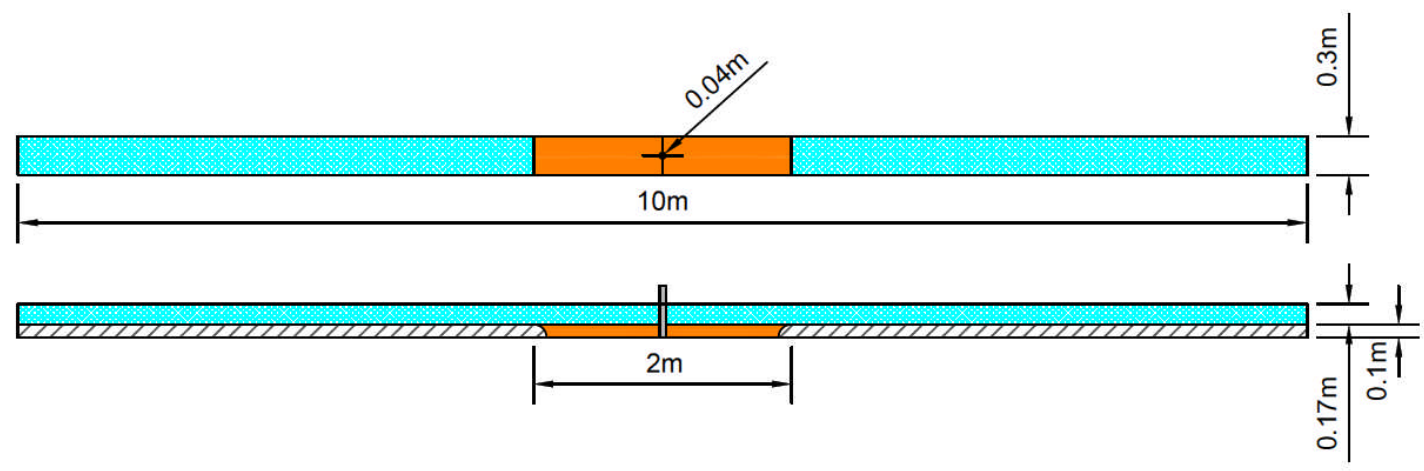

Figure 4. Flume set-up: plan view and side elevation

The pile diameter was chosen so as to avoid the grain size to pile diameter ratio becoming overly significant (Lee and Sturm, 2009), while also reducing the blockage effect to an acceptable level using the rule of thumb proposed by Whitehouse (1998).

The pile was split into sections to improve the set-up procedure. Figure 5 shows the base pile section in the flume prior to filling with sand. This section of the pile consisted of two parts, distinguishable in figure 5 by the grey band towards the middle of the pile section. The upper part above the grey band was unscrewed in order to set up a layered test. The lower layer of sand was placed in the flume and then smoothed over with only the lower part of the pile base in the flume, before the next part of the pile base was screwed in and the next layer of sand was placed in the flume up to the full depth of the bed, and then smoothed at this level. The upper section of the pile from the bed level through to the water surface was then screwed in to start the test. 


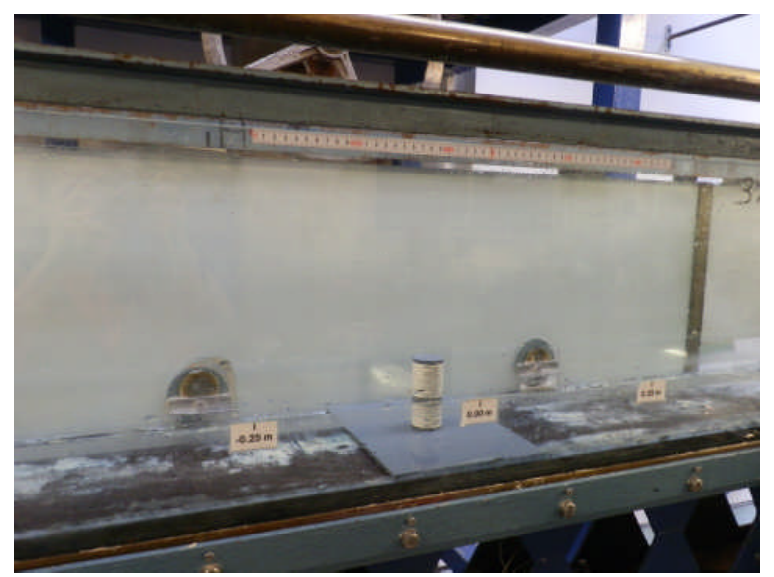

Figure 5. Base section of pile in empty flume

The bed was smoothed using a scraper that rolled along the bars above the flume (figure 6). This device had an adjustable height so that it could smooth at the level of the lower layer as well as at the bed level.

The sand was soaked prior to placing in the flume, and when placed in the flume there was always a depth of water above the bed level, to ensure that no air gaps would be present in the bed.

To set up the mixed test, the sand was mixed dry outside of the flume, before soaking and placing in the flume. When placing this sand in the flume care was taken to fill the bed slowly so as not to cause suspension of finer material and particle sorting, which would reduce the uniformity of the mixture.

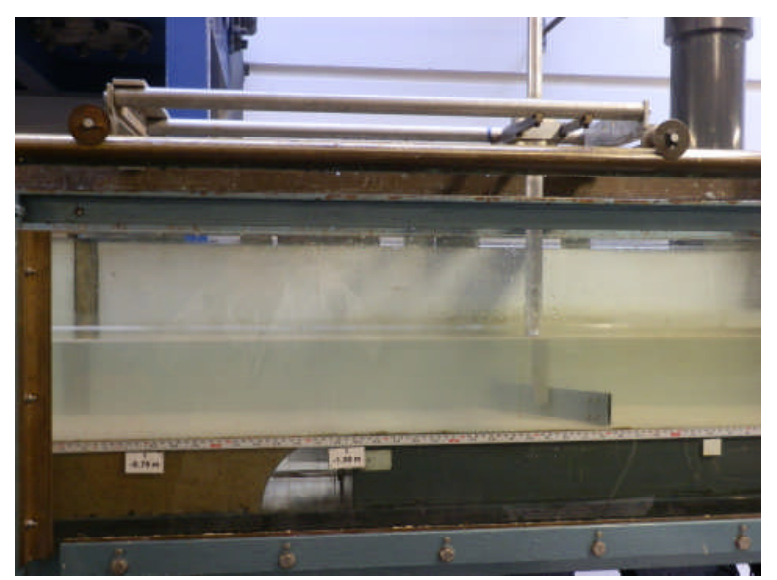

Figure 6. Smoothing device mounted above the flume over the false bed, and showing the transition to the sand bed section

Once the bed was prepared, the water level and velocity were slowly increased without the section of the pile through the water column in place. This meant that a smooth bed could be maintained without any premature scouring occurring before the desired levels had been reached. Once the water depth and velocity were settled, the upper pile section was screwed in to the pile base beginning the test and facilitating as close as possible to an immediate start to the test.

Tables 1, 2 and 3 give the parameters for the uniform, layered and mixed tests respectively. 


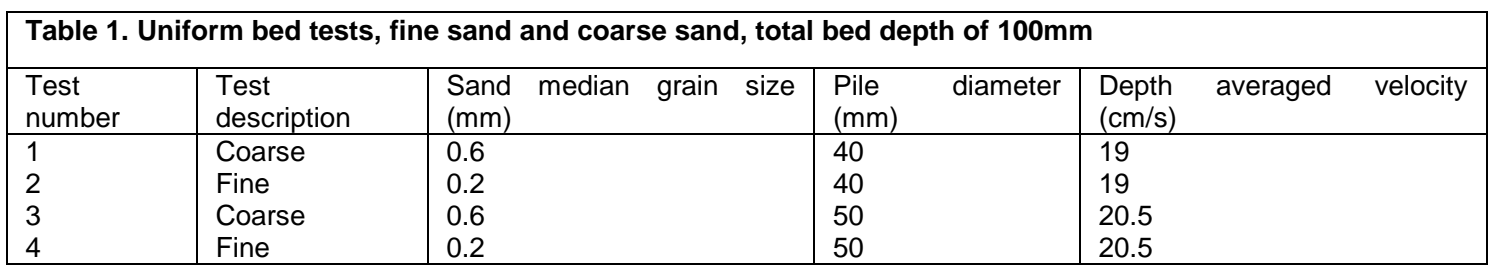

\begin{tabular}{|l|l|l|l|l|l|l|l|l|}
\hline \multicolumn{2}{|l|}{ Table 2. Layered bed tests, fine sand and coarse sand, total bed depth of 100mm } \\
\hline $\begin{array}{l}\text { Test } \\
\text { number }\end{array}$ & $\begin{array}{l}\text { Test } \\
\text { description }\end{array}$ & $\begin{array}{l}\text { Upper layer } \\
\text { median grain } \\
\text { size }(\mathrm{mm})\end{array}$ & $\begin{array}{l}\text { Lower layer } \\
\text { median } \\
\text { grain size } \\
(\mathrm{mm})\end{array}$ & $\begin{array}{l}\text { Upper layer } \\
\text { depth }(\mathrm{mm})\end{array}$ & $\begin{array}{l}\text { Lower layer } \\
\text { depth (mm) }\end{array}$ & $\begin{array}{l}\text { Pile } \\
\text { diameter } \\
(\mathrm{mm})\end{array}$ & $\begin{array}{l}\text { Depth } \\
\text { averaged } \\
\text { velocity } \\
(\mathrm{cm} / \mathrm{s})\end{array}$ \\
\hline 3 & $\begin{array}{l}\text { Fine sand } \\
\text { overlying } \\
\text { coarse sand }\end{array}$ & 0.2 & 0.6 & 50 & 50 & 50 & 20.5 \\
\hline
\end{tabular}

\begin{tabular}{|l|l|l|l|l|l|}
\hline \multicolumn{6}{|l|}{ Table 3. Mixed bed tests, fine sand 0.2mm and coarse sand 0.6mm, total bed depth of 100mm } \\
\hline $\begin{array}{l}\text { Test } \\
\text { number }\end{array}$ & Test description & $\begin{array}{l}\text { Proportion of fine } \\
\text { sand in mix (\%) }\end{array}$ & $\begin{array}{l}\text { Proportion of coarse } \\
\text { sand in mix }(\%)\end{array}$ & $\begin{array}{l}\text { Pile diameter } \\
(\mathrm{mm})\end{array}$ & $\begin{array}{l}\text { Depth averaged } \\
\text { velocity }(\mathrm{cm} / \mathrm{s})\end{array}$ \\
\hline 4 & $\begin{array}{l}\text { Fine and coarse } \\
\text { mixed }\end{array}$ & 50 & 50 & 40 & 19 \\
\hline
\end{tabular}

\section{RESULTS}

Visual observations provided a useful insight into the scour processes occurring during the tests. Figure 7 is an image taken during the layered test where the scour depth has reached into the lower coarse sand layer. The coarse sand is visible in the centre of the scour hole, and the deposition of coarse material directly behind the pile and extending downstream can also be seen. The two sands have not become mixed; there is clear segregation between the upper and lower layers.

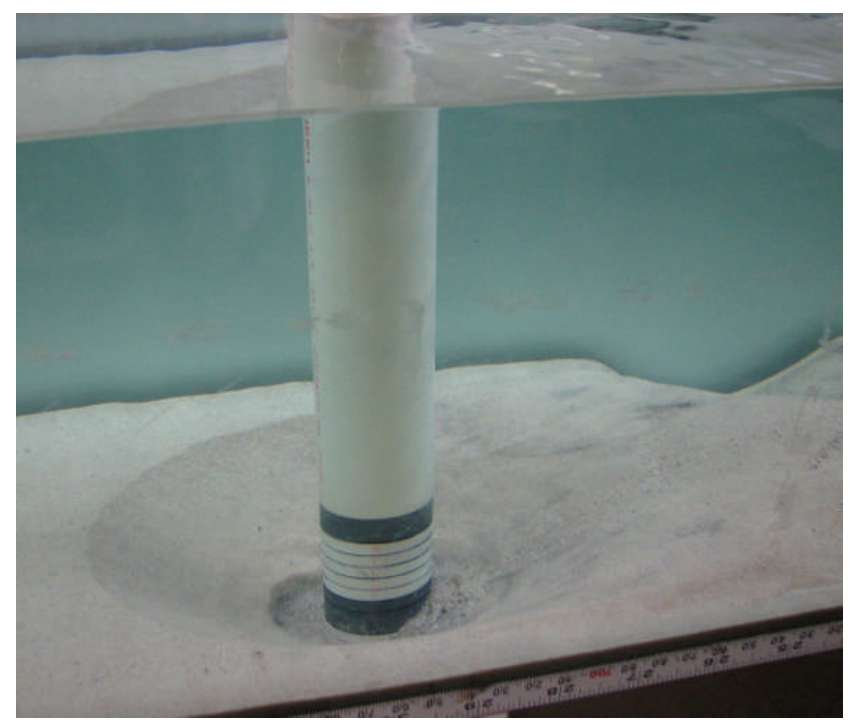

\section{Figure 7. Layered bed test}

It might be anticipated that scour development in each layer would match scour development in the respective uniform cases, so that the relevant sections of the uniform scour curves could simply be superimposed to correctly model the layered bed. To investigate this further, figure 8 shows the scour development through time for the two uniform cases alongside the layered test. Scour in the upper fine sand and lower coarse sand layers in the layered test have been distinguished by different colours on the graph to better visualise the scour development in this case. The initial parts of the uniform find sand curve and the layered test curve match each other closely. In the layered test, this is the section of the curve where scour is through the upper fine sand layer. This means that scour development in the upper layer of fine sand in the layered test is similar to that in the uniform case, as expected. This result 
indicates that the underlying layer of coarse sand does not influence scour development in the fine sand above.

The second part of the layered curve deviates from the fine sand case at the point of the interface between the layers at $\mathrm{S} / \mathrm{D}=1$. From this point, scour develops through the lower layer of coarse sand. This part of the curve should be compared to the uniform coarse sand case. It can be clearly seen from the graph that this section of the curve reaches a greater final scour depth than in the uniform coarse sand case. This means that scour development in the lower coarse sand layer is not similar to scour development in the uniform case, and the sand in the upper layer is actually affecting the amount of scour that occurs in the underlying material. In this layered configuration the scour is enhanced in the underlying coarse sand, meaning that the two uniform cases cannot simply be superimposed to correctly model scour in the layered bed.

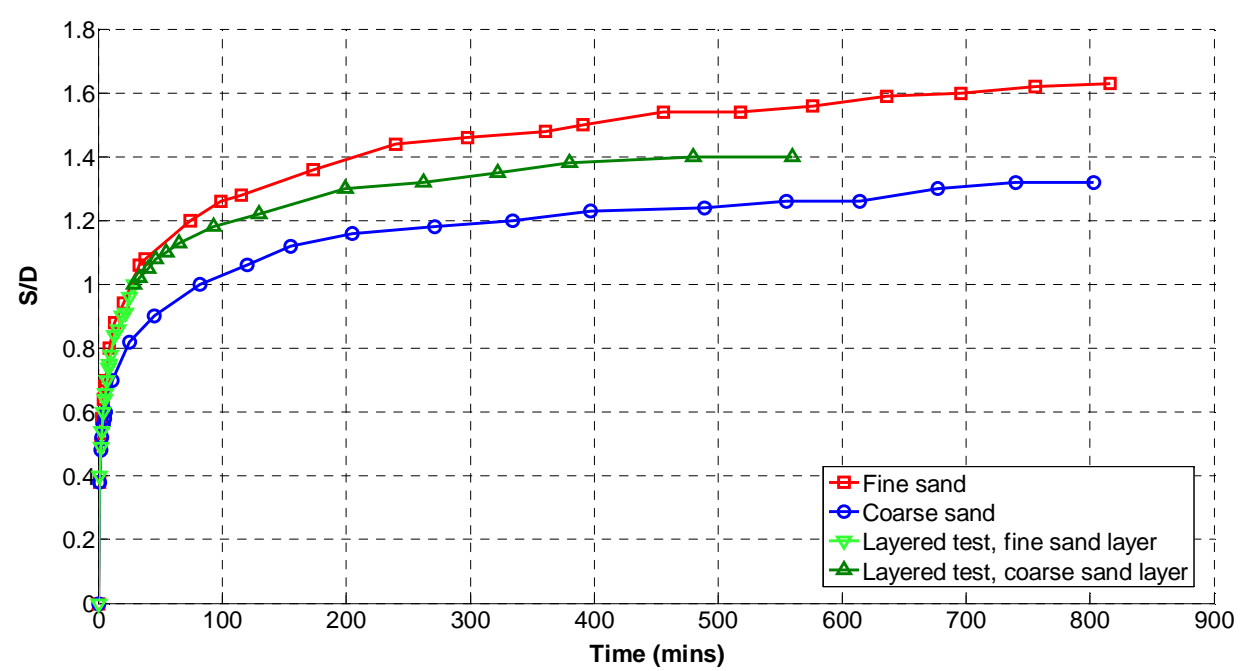

Figure 8. Scour development in the layered test compared to the uniform cases, with scour depth normalized by pile diameter

Figure 9 is an image taken during the mixed test. There are no obvious visual differences to the bed composition at the upstream side of the pile, so no bed armouring has occurred as might be anticipated with this mixture of sands. However, it can be clearly seen that the sand has been sorted in the deposition zone behind the pile, with the coarse sand being deposited directly downstream of the pile, but the fine sand being deposited on either side of the deposition dune.

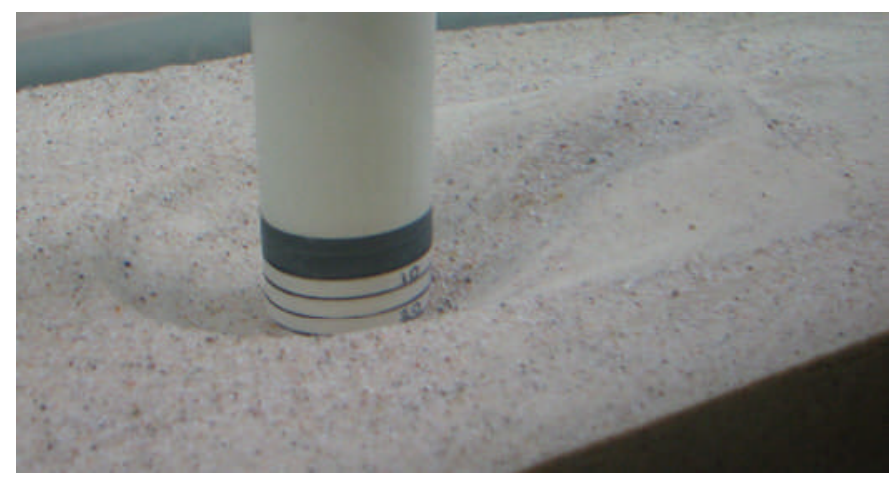

Figure 9. Mixed bed test

The lack of build-up of an armour layer in this case is intriguing, and warrants further analysis. Figure 10 shows the time development of scour in this mixed test. This scour curve is quite different to the expected exponential scour curve. Apart from the initial part of the curve the scour development is approximately linear, and a line has been fitted to demonstrate this in Figure 10. This linear behaviour can be understood by superimposing alternate small sections of the two uniform curves implying that both sands are being eroded at a similar rate as in their respective uniform cases. 


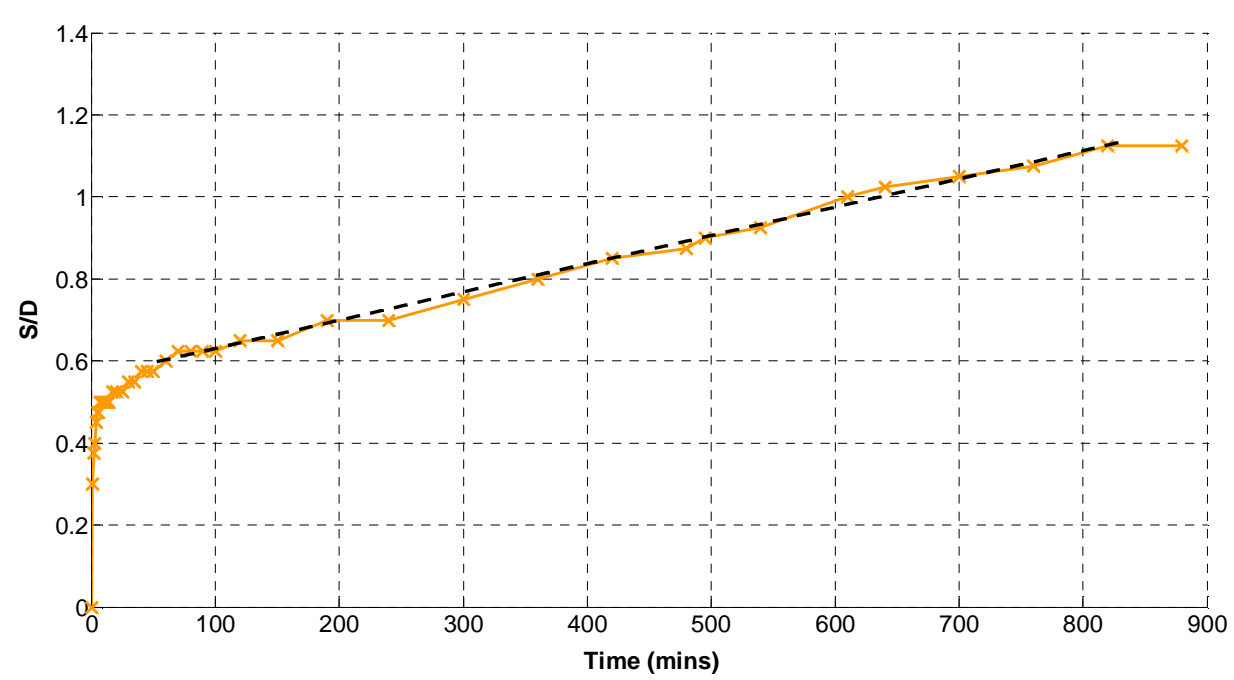

Figure 10. Scour development in the mixed bed test, with scour depth normalized by pile diameter

\section{CONCLUSIONS}

The main conclusions drawn from these tests are:

- In the layered case, scour development in the upper fine sand layer was similar to scour in the uniform fine sand case.

- In the layered case, scour development in the underlying coarse sand layer was enhanced compared to scour from the same depth in a uniform bed of the coarse sand.

- In the mixed case, time development of scour cannot be described in the same way as scour development in a uniform bed.

- In the mixed case, initial scour behaviour is similar to the uniform case, but after this initial phase scour development is almost linear until equilibrium scour depth is reached.

These initial results show that scour behaviour is significantly different in complex sand beds compared to uniform beds. Considering that only two different sized sands have been used in these tests, and the small difference in $\mathrm{d}_{50}$ between the two, this suggests that the influence of more complex layered and mixed non-cohesive beds on scour is likely to be extensive, taking into account wider variations in grain size, greater numbers of layers, different sizes of layers and different proportions of sands within the mixtures.

The alterations to scour depth caused by complex beds make existing scour depth predictive methods inadequate for these bed configurations. Thus, study of scour development in complex noncohesive sediment beds is valuable. The processes behind these changes to scour behaviour should be investigated further and the current tests extended to a wider range of situations and scales in order to provide a more comprehensive coverage of this topic.

\section{FUTURE WORK}

Given the interesting nature of the results from these initial laboratory tests, a further series of tests at larger scale is currently being conducted at UCL, in order to properly quantify the results. A range of layer depths and differing proportions of fine and coarse sand mixtures are being tested. It is planned to conduct a series of tests under reversing flow as well as waves in the near future to investigate the different behaviours of the layered and mixed beds in these conditions. The differences between scour in these beds under clear water and live bed conditions will also be considered.

\section{REFERENCES}

Chiew, Y.M., and B.W. Melville. 1989. Local scour at bridge piers with non-uniform sediments, Proc. Instn Civ. Engrs, Part 2, 87, 215-224.

Debnath, K., and S. Chaudhuri. 2010. Laboratory experiments on local scour around cylinder for clay and clay-sand mixed beds, Engineering Geology, 111, 51-61.

Dey, S., A. Helkjaer, B.M. Sumer, and J. Fredsoe. 2011. Scour at vertical piles in sand-clay mixtures under waves, Journal of Waterway, Port, Coastal and Ocean Engineering, 137(6), 324-331. 
Lee, S.O, and T.W. Sturm. 2009. Effect of sediment size scaling on physical modeling of bridge pier scour, J. Hydraul. Eng, 135(10), 793-802.

Raudkivi, A.J., and R. Ettema, 1977. Effect of sediment gradation on clear water scour, J. Hydraul. Eng, 103, HY10, 1209-1213.

Raudkivi, A.J., and R. Ettema, 1985. Scour at cylindrical bridge piers in armored beds, J. Hydraul. Eng, 111(4), 1209-1213.

Sumer, B.M., and J. Fredsoe. 2002. The mechanics of scour in the marine environment, World Scientific, Singapore, 539 pp.

Ting, F.C.K., J.-L. Briaud, H.C. Chen, R. Gudavalli, S. Perugu, and G. Wei. 2001. Flume tests for scour in clay at circular piers, J. Hydraul. Eng, 127(11), 969-978.

Whitehouse, R.J.S., J.M. Harris, J. Sutherland, and J. Rees. 2010. The nature of scour development and scour protection at offshore windfarim foundations, Marine Pollution Bulletin, 62(1), 73-88.

Whitehouse, R.J.S. 1998. Scour at marine structures: a manual for practical applications, Thomas Telford, London, 207 pp. 